\title{
The lung communication network
}

\author{
Davide Losa $^{1,2} \cdot$ Marc Chanson ${ }^{1}$
}

Received: 4 June 2015/ Accepted: 11 June 2015 / Published online: 23 June 2015

(C) Springer Basel 2015

\begin{abstract}
The different types of cells in the lung, from the conducting airway epithelium to the alveolar epithelium and the pulmonary vasculature, are interconnected by gap junctions. The specific profile of gap junction proteins, the connexins, expressed in these different cell types forms compartments of intercellular communication that can be further shaped by the release of extracellular nucleotides via pannexin1 channels. In this review, we focus on the physiology of connexins and pannexins and describe how this lung communication network modulates lung function and host defenses in conductive and respiratory airways.
\end{abstract}

Keywords Lung - Intercellular communication ·

Connexin · Pannexin · Physiology · Disease

$\begin{array}{ll}\text { Abbreviations } \\ \text { A2B } & \text { Adenosine 2B receptor } \\ \text { ANO1 } & \text { Anoctamin1 } \\ \text { ASL } & \text { Airway surface liquid } \\ \text { ATI } & \text { Alveolar type I cells } \\ \text { ATII } & \text { Alveolar type II cells } \\ \text { ATP } & \text { Adenosine triphosphate } \\ \text { BAL } & \text { Bronchoalveolar lavage } \\ \text { BMSC } & \begin{array}{l}\text { Bone marrow-derived mesenchymal stem or } \\ \text { stromal cells }\end{array} \\ \text { C12 } & N \text {-3-oxo-dodecanoyl-L-homoserine lactone } \\ \text { CaCC } & \text { Calcium-activated chloride channels }\end{array}$

Marc Chanson

marc.chanson@hcuge.ch

1 Geneva University Hospitals and University of Geneva, 1211 Geneva, Switzerland

2 The ithree Institute, University of Technology Sydney, 2007 Ultimo, NSW, Australia
CAMKK $\mathrm{Ca}^{2+} /$ calmodulin-dependent kinase kinase

cAMP Cyclic adenosine monophosphate

CD73 Ecto-5'-nucleotidase

CF Cystic fibrosis

CFTR Cystic fibrosis transmembrane conductance regulator

$\mathrm{Cx}(\mathrm{s}) \quad$ Connexin(s)

ENaC Amiloride-sensitive epithelial channel

FRAP Fluorescence recovery after photobleaching

GJIC Gap junctional intercellular communication

HPV Hypoxic pulmonary vasoconstriction

IL-8 Interleukin-8

$\mathrm{IP}_{3} \quad$ Inositol triphosphate

JNK c-Jun N-terminal kinases

LPS Lipopolysaccharide

$\mathrm{LXA}_{4} \quad$ Lipoxin $\mathrm{A}_{4}$

MAPK Mitogen-activated protein kinase

MSC Mesenchymal stem or stromal cell

NF- $\kappa \mathrm{B} \quad$ Nuclear factor- $\kappa \mathrm{B}$

PAMP Pathogen-associated molecular pattern

Panx(s) Pannexin(s)

$\mathrm{PGE}_{2} \quad$ Prostaglandin $\mathrm{E}_{2}$

P2R Purinergic receptor

PRR Pathogen recognition receptor

TLR Toll-like receptor

TNF- $\alpha \quad$ Tumor necrosis factor- $\alpha$

\section{Introduction}

The lung is the essential organ for breathing and, according to this vital function, is divided in 2 main portions, namely the respiratory portion, the site for gas exchange between air and blood, and the air-conducting portion, the duct for inhaled and exhaled air [1]. The air-conducting portion 
begins above the lungs, extending across most of the respiratory system from the nasal cavities to the intrapulmonary bronchi and the bronchioles, while the respiratory portion is composed of respiratory bronchioles, alveolar ducts, and alveoli entirely located within the lungs. Inhaled air needs to be cleaned from dust, pollen, chemicals, and pathogens present in the environment before it reaches the alveoli for gas exchange. Moreover, recent studies have revealed the presence of a respiratory microbiota, composed by commensal and opportunistic pathogen microbes residing in nose and lungs [2]. Thus, inherent to this organ, an appropriate lung function depends on host defense mechanisms, mainly represented by mucociliary clearance, secretion of antimicrobial molecules and surfactant, innate and adaptive immunity, and also inflammation in case of severe harmful stimuli [3]. The continuous exposure to inhaled hostile factors makes lungs in constant risk of injury and thereby tissue repair processes are also crucial for maintaining lung homeostasis. The latter requires efficient coordination between the different cell types constituting the organ. Here, we describe the cell-to-cell communication network provided by connexins (Cxs) and pannexins (Panxs) in conductive and respiratory airways, and we focus on the physiology of these channels in promoting lung function and host defense.

\section{The lung communication network components: expression and function in lung development and aging}

Cxs form gap junction channels enabling for direct cell-tocell communication, a mechanism referred to as gap junctional intercellular communication (GJIC) [4]. Cxs oligomerize into hexameric structures to form a connexon at the plasma membrane. Connexons between cells in contact dock to form gap junctions, thus directly connecting their cytoplasm and allowing the passage of inorganic ions and small water-soluble molecules. In addition, connexons, also known as hemichannels, can provide direct access for the exchange of small molecules with the extracellular environment [5]. Oligomers of Panxs are similar to connexons at the level of structure and function, but they do not form gap junctions [6]. Panxs are glycoproteins that form single highconductance plasma membrane channels allowing paracrine cell-to-cell communication [7]. In particular, Panx1, which is the most ubiquitously expressed of the 3 Panxs, has been described as a mechano-sensitive adenosine triphosphate (ATP) releasing channel involved in several biological processes. However, in some physiological context, it remains difficult to clearly discriminate between $\mathrm{Cx}$ hemichannels and Panx channels due to their close functional and pharmacological similarities $[8,9]$.
Specific patterns of $\mathrm{Cx}$ and Panx expression have been observed in the lungs depending on species, stages of differentiation, and cell types of the airway tree $[10,11]$. In this paper, we review the expression of Cxs and Panxs in conductive and respiratory airways, and we discuss the involvement of the 2 protein families in the developing and adult lung.

\section{Connexin and pannexin expression in conductive airways}

The air-conducting portion is lined by a pseudostratified epithelium, which is referred to as the airway epithelium, and is formed by basal, ciliated, and mucus-secreting goblet cells [1]. The conductive airways also contain submucosal glands, which are connected with the epithelium through ducts and are mainly composed by mucus-producing cells and serous cells (Fig. 1).

Cx26 and Cx32 are prominent in airway epithelial cells of ferret fetus, but, while gap junctions formed by these Cxs persist in the glandular epithelium up to the weanling stage, their expression declines with ciliogenesis of the superficial airway epithelium and rapidly disappears after birth [12, 13]. Similarly, Cx26 and Cx43 are expressed in the undifferentiated human airway epithelium, but upon differentiation they rapidly disappear [13, 14]. Conversely, Cx30 and Cx31 remain detectable in human differentiated epithelium. Cx30 appears to have mostly apical or lateral localization and to mediate GJIC between ciliated cells and between basal and ciliated cells, whereas $\mathrm{Cx} 31$ is present between few cells localized basally and seems to

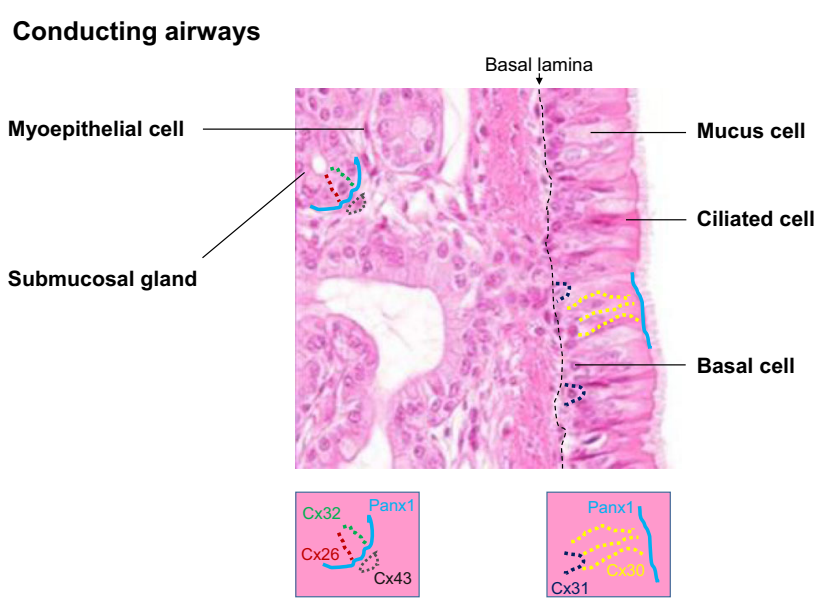

Fig. 1 Expression profile of Panx 1 and principal connexins in the adult conducting airways. Hematoxylin and eosin-stained section of human tracheal mucosa illustrating the surface airway epithelium and the tracheal glands. The localization of connexins and pannexin1 is depicted by a color code and schematically represented below the photograph (Panx1, blue line; $\mathrm{Cx} 26$, red dots; $\mathrm{Cx} 30$, yellow dots; $\mathrm{Cx} 31$; purple dots; $\mathrm{Cx} 32$, green dots; $\mathrm{Cx} 43$, brown dots) 
preferentially connect basal cells [14]. In addition, primary cultures of differentiated human airway epithelial cells have also been found to express mRNAs for Cx30.3 and Cx31.1 [14]. Interestingly, the adult mouse airway epithelium exhibits a similar expression profile for $\mathrm{Cx} 30$ and $\mathrm{C} \times 31$, but, unlike what has been described in humans, Cx26 is present in adult epithelium, although its detection is discontinuous [14], and also Cx37 may be weakly expressed in murine airway epithelium [15-17]. In mouse submucosal glands, $\mathrm{C} \times 26$ and $\mathrm{C} \times 32$ are expressed between the epithelial cells, while $\mathrm{Cx} 43$ is observed between myoepithelial cells surrounding the glands [14].

Panx 1 and Panx 3 protein have been detected in whole murine lungs [18]. Primary cultures of differentiated human airway epithelial cells express mRNAs for Panx1 and Panx2, but not for Panx3 [19]. Panx1 is diffusely expressed in undifferentiated human airway epithelial cells, but its expression increases during differentiation and it is detected apically in ciliated and goblet cells. In addition, submucosal glands express Panx1 preferentially at the basolateral side of the glandular cells [19]. Figure 1 summarizes the profile of $\mathrm{Cx}$ and Panx expression in the conductive airways of the adult lung.

\section{Connexin and pannexin expression in respiratory airways}

In the respiratory portion (Fig. 2), alveoli are lined by a thin epithelial monolayer composed of alveolar type I (ATI) and type II (ATII) cells that are in close contact with the endothelial monolayer of respiratory capillary network [1]. While ATI cells mediate gas exchange and constitute the majority of the alveolar surface, ATII cells absorb actively excessive alveolar liquid and produce surfactant, a major determinant of alveolar patency [20]. The lumen of some alveoli also hosts alveolar macrophages, lung-resident phagocytes that are located in close proximity to the epithelial surface and capillary endothelial cells [21].

Cx26 and Cx43 have been detected in human epithelial cells of the respiratory airways [13, 22, 23]. However, most of our knowledge of $\mathrm{Cx}$ expression in the alveoli comes from murine models. Airway epithelial cells of mouse origin have been found to express Cx26, Cx32, Cx37, $\mathrm{Cx} 43$, and Cx46 [15, 17, 24]. In adult rat alveoli, Cx26, $\mathrm{Cx} 32$, and $\mathrm{Cx} 40$ show moderate staining by immunofluorescence, whereas $\mathrm{Cx} 43$ and $\mathrm{Cx} 46$ are strongly expressed [25-27]. While Cx46 is preferentially detected in ATI cells, Cx32 seems to be restricted in ATII cells for its location in the corners of alveoli. Interestingly, ATI and ATII cells are unable to form functional hetero-cellular gap

\section{Respiratory airways}
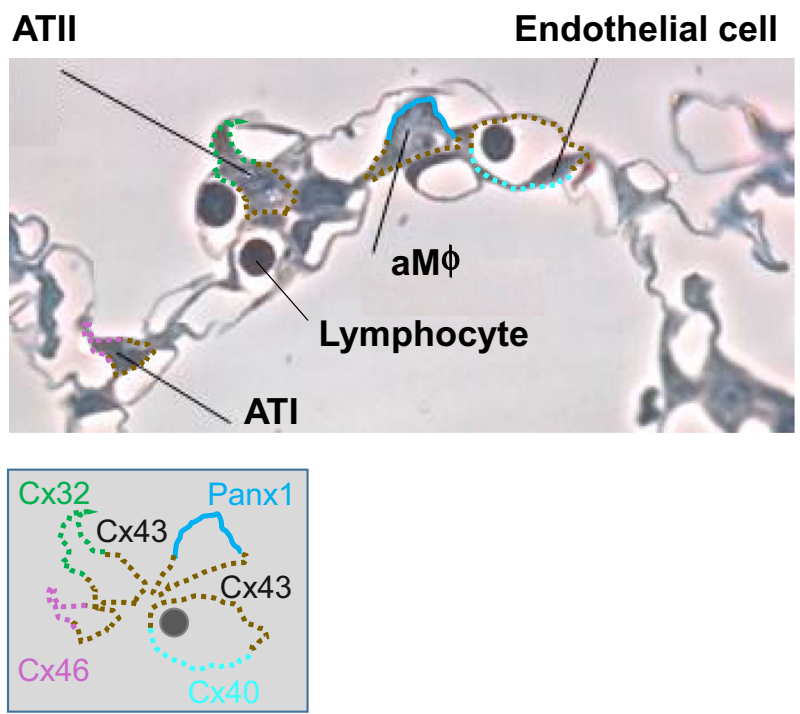

Fig. 2 Expression profile of Panx1 and principal connexins in the adult respiratory airways. Semithin section of human lungs illustrating the respiratory airway epithelium and its relation with the capillary bed. The localization of connexins and pannexin1 is depicted by a color code and schematically represented below the photograph (Panx1, blue line; Cx26, red dots; Cx32, green dots; Cx43, brown dots; $\mathrm{Cx} 40$, light blue dots; $\mathrm{Cx} 46$, pink dots)

junctions via $\mathrm{Cx} 32$ and, even though $\mathrm{C} \times 32$ has the potential to connect ATII cells, ATII cells are rarely adjacent to each other, suggesting an alternative role as hemichannels for Cx32 in these cells [26, 28]. In contrast, Cx43 is fairly distributed in both ATI and ATII cells and is the major Cxmediating GJIC between the 2 cellular types [26]. In mouse, a subset of alveolar macrophages attached to the alveolar wall express Cx43 and form gap junctions with the epithelium [29]. Cx43 is also detected in alveolar endothelial cells together with $\mathrm{Cx} 40$ [30-32], whereas Cx37 is present in endothelium of large lung blood vessels, but not in alveolar capillaries [15].

In alveolar sections of mouse lungs, all the 3 Panxs have been observed. Panx 1 and Panx 3 localize more at the plasma membrane, while Panx2 is expressed in a perinuclear fashion [33]. However, the pattern of Panx expression within the different alveolar cells is not known. The only exception includes isolated human alveolar macrophages, where the mRNA profile of Panxs has been characterized $[19,34]$. Human alveolar macrophages have high levels of Panx1 mRNA. Conversely, Panx2 expression is about 10-fold lower than Panx 1 and Panx 3 mRNA is not detected in these immune cells. Figure 2 summarizes the profile of $\mathrm{Cx}$ and Panx expression in the respiratory airways of the adult lung. 


\section{Connexins and pannexins in lung development and aging}

Being the most abundantly $\mathrm{Cx}$ expressed in lung cells, Cx43 has been found to play a crucial role in lung development. Cx43 gene expression was shown to be downregulated during alveologenesis in a rat model of nitrofen-induced pulmonary hypoplasia, and upregulated in ill rats treated with retinoic acid, which is known to stimulate alveolar formation [35]. Cx43 knockout mice die at birth as a result of a failure in pulmonary gas exchange caused by a swelling and blockage of the right ventricular outflow tract from the heart [36]. A recent analysis of these knockout mice has also shown that their lungs are hypoplastic compared to wild-type mice, with smaller vessels and muscular layer and a strong delay in the development of the alveoli [37]. Airspaces are narrow and alveolar septa are thick, with a decrease in ATI cells and an enrichment of ATII cells in the mesenchyme. However, the mechanism by which $\mathrm{Cx} 43$ regulates lung differentiation is not clear. Failure in alveolar development in $\mathrm{Cx} 43$ knockout mice can be caused by a defect in vessel or epithelial formation, because $\mathrm{Cx} 43$ is expressed in both alveolar endothelial and epithelial cells. Since mice with endothelial-specific deletion of $\mathrm{Cx} 43$ have apparently normal lung development [30, 38], $\mathrm{Cx} 43$ is more likely to play roles in the proliferation/differentiation of epithelial or mesenchymal cells. Conversely, mice double knockout for Cx37 and Cx40, the other 2 main Cxs expressed in endothelial cells, die perinatally, and display severe vascular abnormalities affecting several organs compared to mice lacking either $\mathrm{Cx} 40$ or $\mathrm{Cx} 37$ alone. These include localized hemorrhages in lungs, with extravascular blood present in some of the airspace, which is probably the cause of death for inadequate pulmonary function [39].

The generation and characterization of $\mathrm{Cx}$ knockout mice have been also useful to understand the role of Cxs in the rising of aging-associated lung pathologies. As mentioned, knockout mice deficient for expression of either Cx40 [40] or endothelial Cx43 alone [38] do not exhibit obvious pulmonary alterations. However, adult mice lacking both $\mathrm{Cx} 40$ and endothelial $\mathrm{Cx} 43$ spontaneously develop lung dysfunction and fibrosis, leading to a shortened life span as they age [41]. As early as 16 weeks after birth, these mice begin to exhibit disruption of the alveolar airspaces. Upon aging, lung fibrosis gets worse with alveolar thickening, increased lung fibroblast content, and increased deposition of elastin and collagen in the extracellular matrix. Although the mechanistic basis linking $\mathrm{Cx} 43$ and Cx40 to lung fibrosis is not known, these results suggest that alveolar endothelial Cxs regulate intercellular communication between the vasculature and airspaces, and are important to maintain lung morphology and function. Moreover, lung fibroblasts isolated from patients with idiopathic pulmonary fibrosis have reduced $\mathrm{Cx} 43$ expression and decreased intercellular communication [42]. It remains to be elucidated whether impaired GJIC is involved in activation and proliferation of altered fibroblasts, which are central events in the pathogenesis of this fibrotic pathology [43].

Altered $\mathrm{Cx}$ expression and function have been also described in several lung cancer cells and exogenous tumorigenic agents have been associated with aberrant location or the absence of Cxs expressed in lung [10, 44]. These features have been observed in urethane-induced mouse lung adenomas, where both $\mathrm{Cx} 32$ and $\mathrm{Cx} 43$ were absent [24]. Interestingly, Cx32 knockout mice do not exhibit obvious pulmonary alterations, but they are more susceptible to benzene-induced lung toxicity [45] and have a higher incidence of chemical-induced bronchioloalveolar adenoma [46, 47]. Cx32-deficient non-tumor cells display increased proliferation compared to their wild-type counterparts and lung tumors originate from the proliferationcompetent ATII cells, suggesting that $\mathrm{Cx} 32$ may regulate lung epithelial cell growth under stress conditions [46]. Similarly, a higher incidence of spontaneous and chemicalinduced lung cancer has been described in $\mathrm{Cx} 43^{+/-}$mice with reduced $\mathrm{Cx} 43$ expression in the lung [24, 48, 49]. Deletion of a single allele of $\mathrm{Cx} 43$ leads to lower GJIC capacity and increased cell proliferation of mouse ATII cells [50]. Furthermore, a large number of human lung cancer cell lines shows downregulation of Cx26 expression, which is linked to gene promoter methylation [23]. Nevertheless, the initial assumption suggesting that Cxs would act as tumor suppressor genes has been questioned repeatedly. Indeed, Ito and colleagues showed that the maintenance of $\mathrm{Cx} 26$ expression in human lung squamous cell carcinomas might be related to a higher ability to establish metastasis [51]. Thus, the roles of Cxs and gap junctions in lung carcinogenesis may depend on the stage of the cancer progression and the tumor cell phenotype [52].

Panx expression and function during lung development and aging are unknown. Panxs have been implicated in differentiation of keratinocytes [53], neurons [54, 55], chondrocytes [56], and osteoblasts [57] as well as in tumor progression of glioma cells [58, 59], keratinocytes [60], and mouse melanomas [61]. Surprisingly, given the ubiquitous expression of Panx1 in many tissues, Panx 1 knockout mice do not present any major anatomical abnormalities [7]. Recent analysis of these mice has found that Panx1 regulates cellular properties of keratinocytes 
and dermal fibroblasts in skin development and wound healing [62]. Further studies are needed to address the involvement of Panxs in lung development and aging.

\section{Connexin-dependent and pannexin-dependent communication in conductive airways}

\section{Mucociliary clearance}

The first line of defense against pathogen invasion and external particles is the mucus lining the surface of the airway epithelium [63]. The secreted mucus layer acts as a physical and chemical trap for inhaled hostile factors, which are then removed from the lungs via cough reflex and mucociliary clearance [64]. Ciliary beating was shown to be regulated in a gap junction-dependent mechanism. Indeed, early studies demonstrated that $\mathrm{Cx}$ channels take part in the synchronization of beat frequency in airway cell culture of rabbit origin [65]. Later, it was suggested that the transmission of inositol triphosphate $\left(\mathrm{IP}_{3}\right)$ from one cell to another via gap junctions mediates calcium wave propagation between airway epithelial cells and coordinate ciliary beating [66]. Another mechanism of cell-to-cell communication has been extensively described to coordinate ciliary beating and mucin secretion in response to mechanical stress [67]. This mechanism involves ATP release to the extracellular space, which in turn stimulates type-2 purinergic receptors (P2R) and induces calcium signaling in surrounding ciliated epithelial cells [68]. Recently, the release of ATP induced by hypotonic stress was found to correlate with functional expression of Panx1 channels in differentiated human airway epithelial cells $[19,69]$ as well as in murine airway tissues, while Panx1 knockout mice showed impaired ATP release [19, 70]. However, in other studies, both Cxs and Panxs were found to be involved in ATP release at airway mucosa $[71,72]$. In addition, mucus-secreting airway epithelial cells are able to secrete ATP and other nucleotides within mucin granules by exocytosis [73].

Mucus clearance is facilitated by a thin periciliary liquid layer, which exhibits an optimal height for effective cilia beating [74]. This liquid layer together with the mucus layer forms the airway surface liquid (ASL). The ASL volume is determined by active transepithelial salt transport, involving chloride secretion via cystic fibrosis transmembrane conductance regulator (CFTR) channels and the calcium-activated chloride channel ( $\mathrm{CaCC}$ ) anoctamin1 (ANO1 or TMEM16A), while sodium absorption occurs through the amiloride-sensitive epithelial channel ENaC. Moreover, active chloride release mediates fluid secretion by serous cells to allow the transport of mucus from submucosal glands to the epithelial surface [75].
Interestingly, Cx43-mediated GJIC is required to stimulate mucus hydration in the human glandular epithelial cell line Calu-3 [76]. In fact, inhibition of gap junctions with mimetic-blocking peptides specific for $\mathrm{Cx} 43$ or with pharmacological inhibitors prevents the activation of CFTR-dependent chloride and fluid secretion in response to adenosine, protease-activated, and prostaglandin $\mathrm{E}_{2}\left(\mathrm{PGE}_{2}\right)$ receptor stimulation. These results have been confirmed in human primary airway epithelial cells, where pharmacological inhibition of GJIC results in a failure of $\mathrm{PGE}_{2}$ to increase ASL volume [76]. Pharmacological inhibition of Panx1 channels was also found to abolish the increase of ASL volume induced by lipoxin $\mathrm{A}_{4}\left(\mathrm{LXA}_{4}\right)$ in human airway epithelial cells [77]. $\mathrm{LXA}_{4}$-stimulated ASL volume increase by activating chloride secretion through $\mathrm{CaCCs}$ and by inhibiting ENaC-dependent sodium absorption [78, 79]. $\mathrm{LXA}_{4}$-induced fluid secretion was dependent on apical ATP release via Panx 1 channels and on activation of the purinergic receptor P2RY11 [77].

Collectively, these findings draw a picture in which gap junctions and Panx channels integrate multiple signaling pathways to finely coordinate ciliary beating and mucus hydration. Therefore, the lung communication network provides a mean to maintain efficient mucociliary clearance and, thereby, a proper epithelial host defense [10].

\section{Innate immune response and inflammation}

A successful host response is essential for an orchestrated pathogen clearing in the lungs. The airway innate immune response begins with the identification of pathogen-associated molecular patterns (PAMPs) through pathogen recognition receptors (PRRs) expressed on the host epithelium [80]. PRRs include, among others, toll-like receptors (TLRs), which are transmembrane proteins that can be expressed either on the cell surface or in endosomal compartments [81]. Once TLRs sense a pathogen, they activate signaling pathways, such as mitogen-activated protein kinases (MAPKs), and transcription factors, including nuclear factor- $\kappa \mathrm{B} \quad(\mathrm{NF}-\kappa \mathrm{B})$, to initiate an inflammatory response characterized by the production of cytokines and chemokines, and by apoptosis [81, 82]. In addition, activation of TLRs stimulates epithelial secretion of defense molecules, such as antimicrobial peptides [83, 84] and mucus [85], as well as epithelial fluid efflux for enhancing mucociliary clearance [86-88].

In the human airway epithelial cell line $1 \mathrm{HAEo}^{-}$, binding of bacterial lipoprotein to TLR2 induces immediate calcium-dependent signaling that leads to activation of NF$\kappa \mathrm{B}$ and release of interleukin- 8 (IL-8), a powerful chemoattractant for neutrophil recruitment to the infected area [89]. Interestingly, in lungs of mice infected with the respiratory opportunistic pathogen Pseudomonas aeruginosa, 
recruitment of neutrophils is significantly inhibited by intraperitoneal administration of a pharmacological blocker of gap junctions. The results have been confirmed in vitro, where the same blocker reduces IL- 8 production in response to the pathogen. $\mathrm{Cx} 43$-based gap junctions were shown to transiently amplify this TRL2-induced pro-inflammatory signaling by communicating calcium fluxes from stimulated to adjacent non-stimulated cells [89]. However, this signaling amplification can be attenuated in the presence of lipopolysaccharide (LPS), tumor necrosis factor- $\alpha$ (TNF- $\alpha$ ), and lysophosphatidic acid, which were found to inhibit GJIC by a mechanism dependent on phosphorylation of the Cx43 C-terminus by the tyrosine kinase c-Src [90-92]. Indeed, Pseudomonas aeruginosa induced tyrosine phosphorylation of $\mathrm{Cx} 43$ and decreased GJIC in airway epithelial cells $4 \mathrm{~h}$ post-stimulation prevented excessive NF-kB activation [89]. Thus, this gating regulation of $\mathrm{Cx}$ channels enables the epithelium to immediately respond to bacterial infections, but later it limits the extent of inflammation by a delayed negative feedback elicited by proinflammatory mediators. It is worthwhile to note that in cystic fibrosis (CF) airway epithelial cells, this negative feedback does not occur, which may contribute to the severity of the disease [90-92]. CF, a genetic disease caused by mutations in the $\mathrm{CF}$ transmembrane conductance regulator (CFTR) gene, is characterized by excessive and destructive airway inflammation [93].

Gap junctions were also described to be finely regulated during $P$. aeruginosa infection of polarized submucosal glandular Calu-3 cells [94]. P. aeruginosa flagellin activates cell surface receptors, probably TLR5, to elicit an intracellular MAPK-dependent signaling cascade leading to increased expression of $\mathrm{Cx} 43$ and enhancement of GJIC. Based on the crucial role of GJIC in ASL regulation, upregulation of $\mathrm{Cx} 43$ expression and function may boost CFTR activation and fluid transport in order to counteract bacterial infection [76]. Cx43 was oppositely modulated by MAPKs. Thus, p38 stimulated $\mathrm{Cx} 43$ up-regulation, while c-Jun N-terminal kinases (JNK) exerted a negative regulation. Interestingly, $\mathrm{Cx} 43$-mediated cell-to-cell communication did not affect IL-8 secretion in these glandular epithelial cells, but modulated apoptosis. Apoptosis is important for bacterial clearance from the lungs and for the stimulation of tissue repair $[82,95]$. In addition to strongly enhanced GJIC, inhibition of JNK increased the number of apoptotic cells during bacterial infection. The latter effect was prevented by lentiviral expression of a Cx43-specific short hairpin RNA [94]. Therefore, gap junctions exert a pro-apoptotic role in glandular epithelial cells infected by Pseudomonas aeruginosa, but the tightly regulated expression of $\mathrm{Cx} 43$, mediated by JNK signaling, confers a mechanism to modulate the survival/apoptosis balance. Again, it is worthwhile to mention that this regulation of $\mathrm{Cx} 43$ was altered in $\mathrm{CF}$-like conditions. Indeed, CFTR inhibition in Calu-3 cells was associated with decreased $\mathrm{Cx} 43$ expression and reduced apoptosis [94]. Thus, defective regulation of $\mathrm{Cx} 43$ in $\mathrm{CF}$ airway epithelial cells may contribute to the reduced apoptosis and bacterial killing that has been observed in this disease [96, 97].

\section{Airway epithelial repair}

The recovery of an intact epithelium following infection, inflammation, or injury is critical for restoration of lung homeostasis. The repair process requires the migration and proliferation of local progenitor cells of undamaged areas, which gives rise after re-differentiation to all cell types constituting the airway epithelium [98]. In mice, basal cells have been identified as epithelial progenitor cells, which are able once activated to self-renew and to regenerate ciliated and mucus-secreting cells [98].

$\mathrm{Cx}$ and Panx channels have both been involved in the process of airway epithelial repair. As described above, airway epithelial cells release ATP through Panx 1 channels in response to various stimuli, including $\mathrm{LXA}_{4}$. In addition to induce fluid secretion, $\mathrm{LXA}_{4}$ stimulates epithelial repair [99]. Pharmacological inhibition of Panx1 channels has been found to abolish proliferation of the human airway epithelial cell line NuLi-1 stimulated by $\mathrm{LXA}_{4}$, resulting in decrease wound closure [77]. ATP, upon its release via Panx1 channels, triggers airway epithelial repair by stimulation of P2RY11 receptors, activation of $\mathrm{K}_{\mathrm{ATP}}$ potassium channels, and phosphorylation of extracellular signal-regulated kinases [99]. In contrast, in a wound/healing model of primary cultures of differentiated human airway epithelial cells, $\mathrm{Cx} 26$ has been shown to act as a negative regulator of epithelial cell proliferation [100]. Cx26 is not detectable in differentiated airway epithelial cells [14], but upon wounding, its expression is transiently induced in activated basal cells. Intracellular and some junctional staining of $\mathrm{Cx} 26$ have been detected $12 \mathrm{~h}$ post-wounding in basal cells at the edge of the wound. Its expression markedly increases with time, reaching the peak at $48 \mathrm{~h}$ after injury, when it localizes only at cell-cell contacts and it strongly decreases after wound closure [100]. Activation of cell proliferation upon injury is required to trigger $\mathrm{Cx} 26$ expression in repairing cells, but the signaling factors that regulate $\mathrm{Cx} 26$ induction during repair remained to be identified. Interestingly, Cx26 silencing in immortalized cell lines using small interfering RNA and in non-differentiated primary human airway epithelial cells using lentiviral-transduced short hairpin RNA enhances cell proliferation [100]. The signaling molecules/pathways mediated by GJIC that controls proliferation within repairing epithelial basal cells are unknown. Recently, it 
has been reported that Cx26-based gap junctions redistribute cyclic adenosine monophosphate (cAMP) between cancer cells that, in turn, block cell division [101]. Thus, induction of $\mathrm{Cx} 26$-mediated intercellular communication by proliferative signals in repairing basal cells may represent a feedback mechanism to repress their proliferation and progressively promote differentiation. Interestingly, as described for $\mathrm{Cx} 43$, Cx26 regulation is altered in CF cells. At the early phase of wound repair, primary culture of CFdifferentiated human airway epithelial cells exhibits prompt induction of proliferation and $\mathrm{Cx} 26$ expression even in regions far from the edge of the wound, as well as an enhanced initial rate of wound closure [100]. Furthermore, in $\mathrm{CF}$ and other lung diseases characterized by extensive tissue injury and chronic $P$. aeruginosa infection, proper $\mathrm{Cx}$ function in repairing cells might be also disturbed by quorum-sensing molecule C12 ( $N$-3-oxododecanoyl-L-homoserine lactone), which is highly produced by bacterial biofilm [102]. While an intact polarized epithelium is able to inactivate this molecule, recent data show that $\mathrm{C} 12$ disrupts gap junctions and epithelial integrity by inducing cell shrinkage and blebbing in nonpolarized airway epithelial cells [103]. These effects result in impaired airway epithelial cell repair in wound/healing in vitro model.

\section{Connexin-dependent and pannexin-dependent communication in respiratory airways}

\section{Hypoxic pulmonary vasoconstriction}

Hypoxic pulmonary vasoconstriction (HPV) is a physiological mechanism that improves lung ventilation/ perfusion ratio and arterial oxygenation [104]. Pulmonary arteries constrict in lung areas with low oxygen levels in order to redirect blood flow to alveoli with higher oxygen supply, thereby increasing the total area involved in gaseous exchange. Although pulmonary arterial smooth muscle cells are thought to constitute both the sensor and the transducer of the hypoxic signal as well as its contractile effector, significant controversy remains concerning the underlying mechanisms of local alveolar oxygen sensing and of signal transduction activating vasoconstriction [104].

Interestingly, a recent study has shown that the site for oxygen sensing is located at the alveolo-capillary level with subsequent propagation of the hypoxic signal to upstream arterioles [105]. Inhibition of gap junctions with mimetic-blocking peptides specific for $\mathrm{Cx} 40$ or with pharmacological inhibitors largely attenuates HPV in the lungs of wild-type mice. HPV is also impaired in $\mathrm{Cx} 40$ knockout mice and in mice with endothelial-specific deletion of $\mathrm{Cx} 40$, clearly demonstrating the relevance of $\mathrm{Cx} 40$-based GJIC at the lung vascular endothelium in this mechanism [105]. Hypoxic conditions in wild-type mice induce endothelial membrane depolarization which starts in alveolar capillaries and propagates to neighboring arterioles. The depolarization in upstream vessels is prevented in $\mathrm{Cx} 40$ knockout mice. Therefore, HPV originates at the alveolar site, where hypoxia triggers endothelial membrane depolarization in the capillaries, which is transmitted by electric coupling via $\mathrm{Cx} 40$-based gap junctions to the upstream arterioles. At this site, the hypoxic-transmitted signal elicits vasoconstriction through a signaling cascade induced by endothelial membrane depolarization and involving activation of endothelial voltage-dependent $\alpha 1 \mathrm{G}$ subtype calcium channels, cytosolic phospholipase A2, and formation of epoxyeicosatrienoic acids, which may stimulate arterial smooth muscle cell contraction [105].

Strikingly, although HPV is a physiological process, it can lead to pulmonary hypertension under conditions of chronic lung hypoxia [104]. Interestingly, chronic hypoxic pulmonary hypertension is attenuated in $\mathrm{Cx} 40$ knockout mice, suggesting that $\mathrm{Cx} 40$ is not only required for physiological HPV, but is also involved in lung vascular remodeling and pulmonary hypertension in response to chronic hypoxia [105]. Furthermore, induction of pulmonary hypertension in rats by chronic hypoxia or pharmacological treatment increases the expression of Cx43 at the lung arterial wall [106, 107]. Since inhibition of $\mathrm{Cx} 43$ with blocking peptides tends to decrease HPV [105], the role of this Cx in mediating HPV may become deleterious during pulmonary hypertension, representing a potential target for the treatment of this disease [10].

\section{Surfactant secretion}

In the lower airways, surfactant released by ATII cells is required for the reduction of alveolar surface tension to prevent collapse of the lungs (atelectasis) during the ventilatory cycle and for protection against reactive oxygen lung injuries and infections [20]. Lung surfactant consists of glycerophospholipids packaged into specialized organelles termed lamellar bodies, which are delivered by exocytosis to the apical cell surface. This exocytosis is triggered by an increase in cytosolic calcium concentration. ATI cells, which represent $90 \%$ of alveolar cells and that are more subjected to mechanical stress, promote the release of surfactants by ATII cells through calcium wave propagation $[26,108]$. In isolated intact rat alveoli, photoexcited release of caged calcium inside the alveolar epithelial cells was performed to study the transmission of calcium [108]. This technique led to an increase of calcium concentration in the cytosol of selected cells and induced ATII cell secretion, even when photo-excited cells were 
ATI cells. Furthermore, GJIC also enables calcium wave propagation from one alveolus to the neighboring ones. Interestingly, the interalveolar communication involving ATI and ATII cells was blocked by mimetic-blocking peptides specific for $\mathrm{Cx} 43$ [108]. Thus, calcium signaling is propagated within the alveolar epithelium through $\mathrm{Cx} 43$ based gap junctions, leading to ATII surfactant secretion. It is important to note that in response to mechanical stretch transmission of calcium waves from ATI to ATII cells and the resulting surfactant secretion can also occur via paracrine stimulation of P2R through ATP release [27, 109]. Pharmacological and peptide inhibitors of Cxs have no effect on this paracrine cell-to-cell communication [109], suggesting that in alveolar epithelial cells, ATP can be release through Panx channels and/or by exocytosis. Therefore, propagation of calcium signals, either via gap junctions or via paracrine ATP release, is crucial to modulate surfactant secretion and may also help to adjust surfactant production to stimuli such as changes in pulmonary blood pressure $[110,111]$.

\section{Alveolar macrophage-driven immune response}

In healthy humans, alveolar macrophages are most likely the only immune cells present in the alveoli, representing the sentinel phagocytic cells of the innate immune system in the lungs [21]. The innate immune response of macrophage-like cells involves the activation of inflammasomes, which are large multiprotein complexes for proper maturation and secretion of the pro-inflammatory cytokines IL$1 \beta$ and IL-18, and for induction of apoptosis/pyroptosis [112]. Although an early report has found that Panx1 interacts with $\mathrm{P} 2 \mathrm{X} 7$ receptor to activate inflammasomes [34], its requirement for this innate immune response is still controversial [113].

Induction of inflammasome signaling, ascribed primarily to the alveolar macrophage, has been demonstrated to impair Pseudomonas aeruginosa clearance and to increase apoptosis/pyroptosis and mortality in murine acute pneumonia [114]. Interestingly, pharmacological inhibition of Panx 1 channels by probenecid enhanced bacterial clearance by reducing levels of IL-1 $\beta$ in lung of mice affected by acute $P$. aeruginosa pneumonia [115]. In addition, the authors showed that probenecid also inhibited in vitro IL-1 $\beta$ secretion by murine alveolar macrophages upon bacterial infection. Therefore, probenecid inhibition of Panx1-dependent inflammasome activation in alveolar macrophages has been proposed as therapeutic option to reduce the negative consequences of inflammation in acute $P$. aeruginosa pneumonia [115]. Conversely, in agreement with previous studies showing that inflammasome activation is required for protective immunity in the lung against Streptococcus pneumoniae infection [116, 117], probenecid treatment in mice infected with $S$. pneumoniae did not improve the clearance of this bacterium from the lung. On the contrary, the number of viable $S$. pneumoniae was even augmented in bronchoalveolar lavage (BAL) of treated mice [115].

A recent study has demonstrated intercellular communication occurring in the alveolar lumen between resident macrophages and epithelial cells [29]. Formation of gap junctions between sessile macrophages and the epithelium was demonstrated by cell-specific photo-excited release of caged calcium and fluorescence recovery after photobleaching (FRAP). In $40 \%$ of alveolar macrophages, uncaging-induced calcium waves spread from the epithelium to macrophages and in the opposite direction. Treatment with mimetic peptides specific for Cx43 abolished this communication. FRAP techniques and $\mathrm{Cx} 43$ staining revealed the presence of "Cx43-high" coupled and "Cx43-low" uncoupled alveolar macrophage populations. Cx43 expression was more abundant in murine macrophages attached to the alveolar wall than non-adherent macrophages isolated by BAL, indicating that this resident population is able to form gap junctions with the alveolar epithelium. Furthermore, exposure of lung alveoli to Escherichia coli LPS-induced cyclic and synchronized calcium spikes in both macrophages and epithelial cells. The spikes propagated between different alveolar macrophages, often separated by several alveoli, across the intervening epithelium. These calcium waves were inhibited by $\mathrm{Cx} 43$ blockers, but not by $\mathrm{P} 2 \mathrm{R}$ antagonists, ruling out a role for $\mathrm{Cx}$ hemichannels in this cell-to-cell communication mechanism. Mice with either alveolar macrophage-specific or alveolar epithelial-specific deletion of Cx43 lacked LPS-induced synchronized calcium spikes. Importantly, in response to LPS treatment, these mice also showed an increase in different inflammatory parameters, including nuclear translocation of $\mathrm{NF}-\kappa \mathrm{B}$, production of pro-inflammatory cytokines and chemokines, recruitment of neutrophils to alveoli, and higher mortality as compared to wild-type mice. The anti-inflammatory signals induced by calcium wave transmission involved calcium/calmodulin-dependent kinase kinase (CAMKK) and phosphorylation in alveolar epithelial cells of its downstream target, namely the pro-survival kinase Akt. All together, these findings indicate that in the alveolar lumen, Cx43-based GJIC between resident macrophages and the epithelium modulates the extent of the inflammatory response against bacterial pathogens and protects from acute lung injury.

\section{Leukocyte recruitment in the alveolar lumen}

Chemokines and inflammatory mediators activate and guide leukocytes to inflamed tissues by stimulating chemotaxis, a 
complex process that involves recognition of chemotactic gradients, cell polarization, and directed migration [118]. Panx 1 channels have been demonstrated to control several aspects of human neutrophil chemotaxis by mediating ATP release and autocrine purinergic signaling [119, 120]. Extracellular nucleotides also act as potent mediators of lung inflammation, providing a paracrine mechanism for intercellular communication between leukocytes and cells present in the alveoli [121]. In a murine model of lung fibrosis induced by airway administration of bleomycin, ATP released into the alveolar lumen was shown to constitute a major endogenous danger signal that engages the $\mathrm{P} 2 \mathrm{X} 7$ receptor Panx1 axis, leading to IL-1 $\beta$ maturation, leukocyte recruitment, and lung fibrosis [122]. Indeed, acute inflammation was reduced by mimetic-blocking peptides specific for Panx1. Furthermore, based on in vitro experiments, it has been proposed that airway and alveolar epithelial cells underlie increased levels of luminal ATP during lung fibrosis [122]. However, ATP release by pulmonary epithelial cells in response to bleomycin treatment was only partially inhibited by Panx blockers, suggesting that other mechanisms, such as Cx hemichannels, exocytosis, and/or membrane leakage of damaged cells, might be responsible for increased levels of extracellular nucleotides. Similarly, stress inflammatory conditions also induce massive release of ATP from endothelial cells [121]. Activated leukocytes were also proposed as a source of enhanced levels of extracellular ATP through release via Cx37 hemichannels for monocytes [123] and Cx43 hemichannels for neutrophils [124], although Panx1 channels may fulfill similar functions.

The ability of gap junctions to propagate inflammatory signals has been clearly shown to be crucial in the endothelium to mediate the adhesion and the transmigration of neutrophils in the alveolar space of inflamed lungs. The lung microvascular $\mathrm{Cx} 40$ and $\mathrm{Cx} 43$ show opposite expression patterns and function during acute lung inflammation [10]. Cx40 expression was found to decrease in response to lung injury in rabbits and this phenotype has been associated with increased pulmonary vascular permeability [125, 126]. Intranasal instillation of E. coli LPS in mice also reduced pulmonary Cx40 expression, but the development of inflammation did not differ between wild-type and Cx40 knockout mice [127]. In contrast, increased recruitment of neutrophils to the alveoli was observed in mice with endothelial-specific deletion of $\mathrm{Cx} 40$ early during the inflammatory response to intratracheal instillation of LPS from $P$. aeruginosa [32]. Furthermore, murine lung capillaries lacking endothelial Cx40 showed decreased activity of ecto-5'nucleotidase (CD73), the ectoenzyme that hydrolyzes extracellular nucleotides to generate adenosine. Several studies indicate that production of adenosine has a protective role in acute lung inflammation [128]. Adenosine produced by CD73 prevents leukocyte adhesion to the endothelium via an intracellular cAMP signaling triggered by stimulation of A2B receptors [129]. Interestingly, targeting endothelial Cx40 in vitro reduced GJIC and CD73 expression and activity, resulting in enhanced leukocyte adhesion to a mouse endothelial cell line. Moreover, it has been shown that adenosine enhances $\mathrm{Cx} 40$-mediated GJIC, enabling the propagation of anti-adhesion signaling between endothelial cells [32].

In contrast to $\mathrm{Cx} 40, \mathrm{Cx} 43$ expression increases during the acute phase of inflammation at alveolar septa of damaged lungs [130]. Inhibition of Cx43-based gap junctions was found to block the increase of endothelial barrier permeability, which is responsible for alveolar edema, induced by lung acid injury [131]. Intratracheal instillation of $P$. aeruginosa LPS also increased the expression of Cx43 in mouse alveolar compartment [31]. In this study, the pro-inflammatory role for this $\mathrm{Cx}$ was demonstrated in vivo using $\mathrm{Cx} 43^{+/-}$mice with reduced $\mathrm{Cx} 43$ expression in the lung. These mice showed decreased neutrophil recruitment to the alveolar space $24 \mathrm{~h}$ after induction of lung inflammation. Conversely, mice expressing a truncated Cx43 protein at amino acid 257, causing the formation of $\mathrm{Cx} 43$ channels that remain mostly open due to lack of regulatory motifs present in the C-terminus [132], exhibit increased neutrophil recruitment during acute lung inflammation [31]. Furthermore, mimetic-blocking peptides specific for $\mathrm{Cx} 43$ reduced adhesion of leukocytes to the surface of murine alveolar and endothelial cell lines, while treatment of wild-type mice with peptides reduced recruitment of neutrophils and promoted the resolution of inflammation in response to LPS instillation. Consistent with this model, imaging of the intact perfused lung showed evidence of calcium waves that propagate along pulmonary vessels through Cx43-based gap junctions [30]. A consequence of this $\mathrm{Cx} 43$-dependent conduction is the expression at the surface of venular endothelial cells of the leukocyte adhesion molecule P-selectin in response to an increase in calcium level in the alveolar capillary bed, thereby facilitating the transmigration of neutrophils and leukocytes across the thin alveolar endothelial-epithelial barrier. Thus, Cx40-based and Cx43-based gap junctions with their specificity in propagating pro-inflammatory or anti-inflammatory signals between endothelial cells appear as key modulators of neutrophil recruitment during acute lung inflammation. While $\mathrm{Cx} 40$ delays the adhesion of neutrophils to the endothelial cells early during the inflammatory response, $\mathrm{Cx} 43$ promotes their transmigration across the alveolar wall during the acute phase of inflammation. 


\section{Alveolar barrier repair}

Recovery of proper respiratory function after lung injury requires the restoration of an intact and a functional alveolar barrier able to drain alveolar edema fluid and secrete surfactant [133]. Although ATII cells have been classically considered the only cells that can repopulate denuded alveolar epithelium, recent studies in murine model have identified progenitor cells in strategically located niches in the distal lung that contributes to alveolar repair mechanisms [133]. Cell-based therapies that have been shown to reduce lung injury and to enhance lung repair in murine models could be beneficial for treating patients with severe acute lung inflammation and injury. Novel treatment strategies include the administration of allogeneic mesenchymal stem or stromal cells (MSCs), which are connective tissue progenitor cells with multilineage differentiation potential [134]. These stem cells can be isolated not only from adult bone marrow, but also from several non-hematopoietic organs, including the lungs [135]. Interestingly, once engrafted in the lungs, MSCs are able to communicate with locally resident alveolar epithelial cells via gap junctions [136]. In a recent elegant study, Islam and colleagues have proposed an intriguing function for gap junctions in the context of MSC-based therapy for severe lung injury [137]. Using live-lung FRAP microscopy and Cx43-blocking peptides, Cx43-dependent GJIC between MSCs and alveolar epithelial cells was confirmed in murine lung after intratracheal administration of mice bone marrow-derived MSCs (BMSCs). However, formation of gap junctions occurred only under acute lung inflammation induced by $E$. coli LPS. In control mice treated with phosphate buffer, BMSCs were detected outside of the alveoli in pleural interstitia and in thoracic lymph nodes. As previously described, LPS increased the expression of $\mathrm{Cx} 43$ in alveoli, creating a $\mathrm{Cx} 43$-rich alveolar environment that is required for the attachment of BMSCs. Indeed, GJIC was essential for BMSCs placement at the alveoli, because mouse BMSCs expressing a dominant-negative mutant of $\mathrm{Cx} 43$ $\left(\mathrm{C} \times 43^{\mathrm{T} 154 \mathrm{~A}}\right)$, resulting in the formation of closed gap junctions [138], did not communicate with epithelial cells and migrated more out of the lung [137]. LPSinduced acute lung inflammation and injury were markedly reduced by instillation of mouse BMSCs, as indicated by decreased leukocyte recruitment and alveolar barrier permeability, restoration of surfactant secretion and increase survival. In contrast, administration of BMSCs expressing $\mathrm{Cx} 43^{\mathrm{T} 154 \mathrm{~A}}$ or small interfering RNA against $\mathrm{Cx} 43$ did not ameliorate the severity of the disease. The beneficial effects exerted by BMSCs required GJIC and were dependent on the ability of these cells to transfer mitochondria and supply bioenergy to the damage alveolar epithelial cells. In fact, the establishment of GJIC during alveolar attachment was shown to trigger an intracellular calcium rise in mouse BMSCs, which in turn formed nanotubes and released microvesicles containing mitochondria. BMSC-derived microvesicles were then engulfed via endocytosis by ATII cells, thereby, transferring their mitochondrial contents to the alveolar epithelium. This transfer resulted in enhanced intracellular ATP production in the inflamed lung, providing supplemental energy that may help the recovery of the alveolar cells [137].

Although other paracrine and cell contact-independent mechanisms are likely to also contribute to improved lung healing and function by MSCs in acute inflammatory diseases [133], these findings indicate that GJIC is crucial to mediate some therapeutic effects of MSCs in the repair of the alveolar barrier function. These findings should open the way for future studies addressing the role of Cxs and Panxs in lung-resident stem cells and their involvement in lung repair.
Fig. 3 Principal functions of Panx 1 and connexins in the adult conducting airways. The functions mediated by Cxs or Panx1 for given stimulus are indicated by a color code (ASL airway surface liquid, $L X A 4$ lipoxin $\mathrm{A} 4, A T P$ adenosine triphosphate)

\section{Conducting airways}

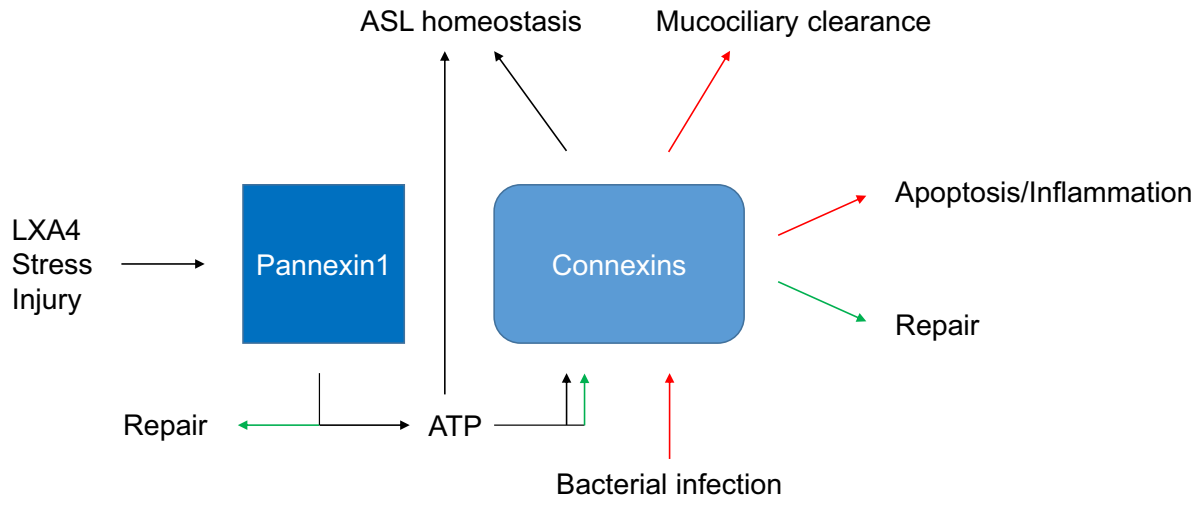


Fig. 4 Principal functions of Panx 1 and connexins in the adult respiratory airways. The functions mediated by Cxs or indicated by a color code. The basal lamina separating the airblood compartments is indicated by a blue dashed line (ADO adenosine, $A T P$ adenosine triphosphate, $C D 73$ ecto- $5^{\prime}-$ nucleotidase) Panx1 for given stimulus are

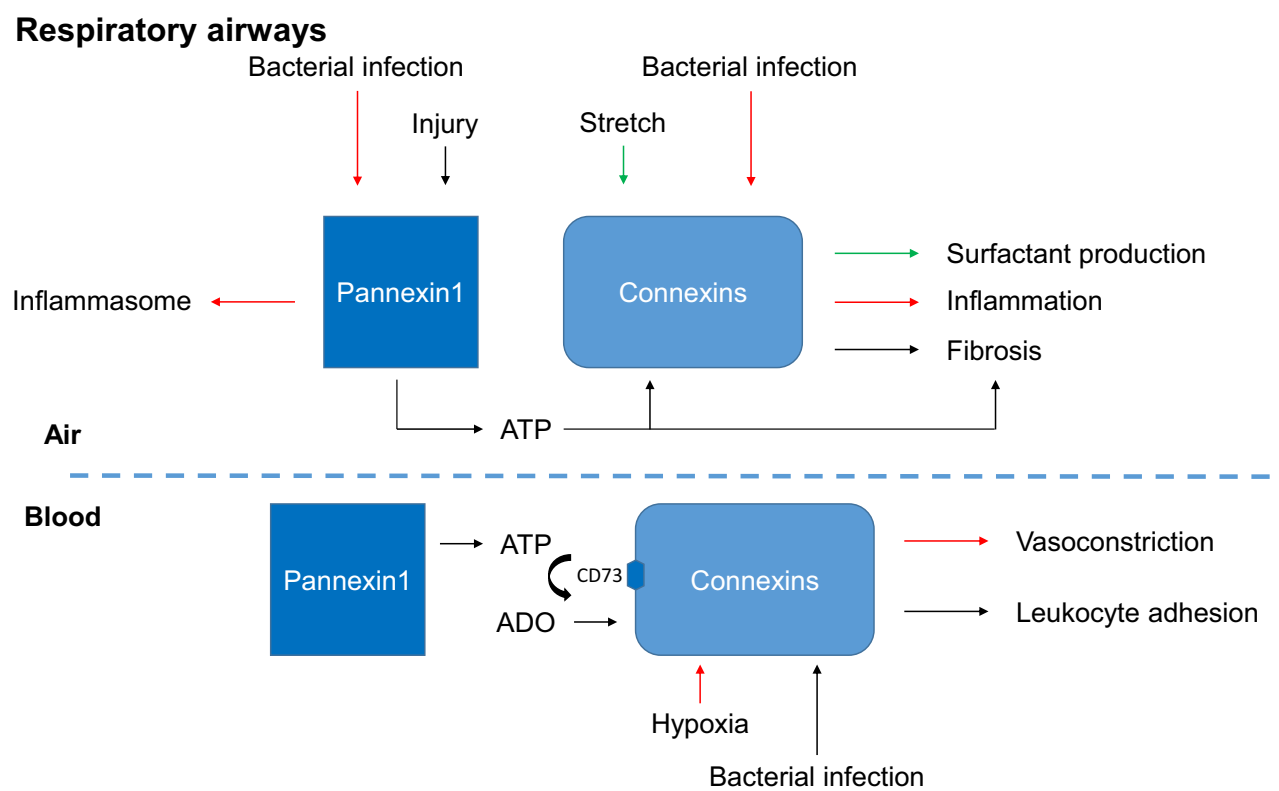

Acknowledgments This work was supported by the Swiss National Science Foundation and the "Fondation pour des Bourses d'Etudes Italo-Suisses.”

Conflict of interest The authors declare that the research was conducted in the absence of any commercial or financial relationship that could be construed as a potential conflict of interest.

\section{References}

optimal oxygen supply. The inhaled air is filtered in the conductive airways by mucociliary clearance and, when needed, bacterial clearance is promoted via several inflammatory mechanisms involving macrophages, endothelial, and epithelial cells. In response to injury a repair process is engaged, although fibrosis can also occur [3]. To fulfill these critical functions, the different cells of the lung act as integrated systems enabled by Cxs and Panxs, which regulate extracellular and intercellular signaling, control the flow of metabolites, and restrict the flow of toxic agents. The roles of Panx 1 and Cxs in the airway epithelium and the alveolar barrier of the adult lung are summarized in Figs. 3 and 4. While a diversity of gap junction proteins is involved in coupling epithelial cells and non-epithelial cells in the lung, Cx43, Cx40, and Panx1 appear so far to have critical roles in intercellular communications among epithelial cells, endothelial cells, and macrophages. Clearly, more has to be understood regarding the physiological roles of Cxs and Panxs in lung functions, which may provide the foundation to determine whether targeting these intercellular communication pathways represent an efficient approach to the treatment of lung pathologies [10].
1. Kierszenbaum AL (2002) Histology and cell biology : an introduction to pathology. Mosby, St. Louis

2. Gollwitzer ES, Marsland BJ (2014) Microbiota abnormalities in inflammatory airway diseases: potential for therapy. Pharmacol Ther 141(1):32-39. doi:10.1016/j.pharmthera.2013.08.002

3. Whitsett JA, Alenghat T (2015) Respiratory epithelial cells orchestrate pulmonary innate immunity. Nat Immunol 16(1):27-35. doi:10.1038/ni.3045

4. Goodenough DA, Paul DL (2009) Gap junctions. Cold Spring Harb Perspect Biol 1(1):a002576. doi:10.1101/cshperspect. a002576

5. Saez JC, Leybaert L (2014) Hunting for connexin hemichannels. FEBS Lett 588(8):1205-1211. doi:10.1016/j.febslet.2014.03. 004

6. Sosinsky GE, Boassa D, Dermietzel R, Duffy HS, Laird DW, MacVicar B, Naus CC, Penuela S, Scemes E, Spray DC, Thompson RJ, Zhao HB, Dahl G (2011) Pannexin channels are not gap junction hemichannels. Channels (Austin) 5(3):193-197

7. Penuela S, Gehi R, Laird DW (2013) The biochemistry and function of pannexin channels. Biochim Biophys Acta 1828(1):15-22. doi:10.1016/j.bbamem.2012.01.017

8. Wang N, De Bock M, Decrock E, Bol M, Gadicherla A, Vinken M, Rogiers V, Bukauskas FF, Bultynck G, Leybaert L (2013) Paracrine signaling through plasma membrane hemichannels. Biochim Biophys Acta 1828(1):35-50. doi:10.1016/j.bbamem. 2012.07.002 
9. Dahl G, Qiu F, Wang J (2013) The bizarre pharmacology of the ATP release channel pannexin1. Neuropharmacology 75:583-593. doi:10.1016/j.neuropharm.2013.02.019

10. Losa D, Chanson M, Crespin S (2011) Connexins as therapeutic targets in lung disease. Expert Opin Ther Targets 15(8):989-1002. doi:10.1517/14728222.2011.584875

11. Johnson LN, Koval M (2009) Cross-talk between pulmonary injury, oxidant stress, and gap junctional communication. Antioxid Redox Signal 11(2):355-367. doi:10.1089/ars.2008.2183

12. Carson JL, Collier AM, Hu SC, McLachlan JB (1995) Variability in distribution and populations of gap junctions in ferret trachea during postnatal development. Am J Physiol 268(4 Pt 1):L576-L583

13. Carson JL, Reed W, Moats-Staats BM, Brighton LE, Gambling TM, Hu SC, Collier AM (1998) Connexin 26 expression in human and ferret airways and lung during development. Am J Respir Cell Mol Biol 18(1):111-119

14. Wiszniewski L, Sanz J, Scerri I, Gasparotto E, Dudez T, Lacroix JS, Suter S, Gallati S, Chanson M (2007) Functional expression of connexin30 and connexin31 in the polarized human airway epithelium. Differentiation 75(5):382-392. doi:10.1111/j.14320436.2007.00157.x

15. Traub O, Hertlein B, Kasper M, Eckert R, Krisciukaitis A, Hulser D, Willecke K (1998) Characterization of the gap junction protein connexin37 in murine endothelium, respiratory epithelium, and after transfection in human HeLa cells. Eur J Cell Biol 77(4):313-322. doi:10.1016/S0171-9335(98)80090-3

16. Park SJ, Lee KS, Kim SR, Min KH, Lee KY, Choe YH, Park SY, Hong SH, Lee YC (2007) Change of connexin 37 in allergeninduced airway inflammation. Exp Mol Med 39(5):629-640

17. Udaka N, Miyagi Y, Ito T (2007) Connexin expression in mouse lung tumor. Cancer Lett 246(1-2):224-229. doi:10.1016/j. canlet.2006.02.020

18. Penuela S, Bhalla R, Gong XQ, Cowan KN, Celetti SJ, Cowan BJ, Bai D, Shao Q, Laird DW (2007) Pannexin 1 and pannexin 3 are glycoproteins that exhibit many distinct characteristics from the connexin family of gap junction proteins. J Cell Sci $120(\mathrm{Pt}$ 21):3772-3783. doi:10.1242/jcs.009514

19. Ransford GA, Fregien N, Qiu F, Dahl G, Conner GE, Salathe M (2009) Pannexin 1 contributes to ATP release in airway epithelia. Am J Respir Cell Mol Biol 41(5):525-534. doi:10. 1165/rcmb.2008-0367OC

20. Andreeva AV, Kutuzov MA, Voyno-Yasenetskaya TA (2007) Regulation of surfactant secretion in alveolar type II cells. Am J Physiol Lung Cell Mol Physiol 293(2):L259-L271. doi:10.1152/ ajplung.00112.2007

21. Kopf M, Schneider C, Nobs SP (2015) The development and function of lung-resident macrophages and dendritic cells. Nat Immunol 16(1):36-44. doi:10.1038/ni.3052

22. Cesen-Cummings K, Fernstrom MJ, Malkinson AM, Ruch RJ (1998) Frequent reduction of gap junctional intercellular communication and connexin43 expression in human and mouse lung carcinoma cells. Carcinogenesis 19(1):61-67

23. Chen Y, Huhn D, Knosel T, Pacyna-Gengelbach M, Deutschmann N, Petersen I (2005) Downregulation of connexin 26 in human lung cancer is related to promoter methylation. Int $\mathbf{J}$ Cancer 113(1):14-21. doi:10.1002/ijc.20498

24. Avanzo JL, Mesnil M, Hernandez-Blazquez FJ, da Silva TC, Fukumasu H, Mori CM, Yamasaki H, Dagli ML (2006) Altered expression of connexins in urethane-induced mouse lung adenomas. Life Sci 79(23):2202-2208. doi:10.1016/j.lfs.2006.07. 033

25. Lee YC, Yellowley CE, Li Z, Donahue HJ, Rannels DE (1997) Expression of functional gap junctions in cultured pulmonary alveolar epithelial cells. Am J Physiol 272(6 Pt 1):L1105-L1114
26. Abraham V, Chou ML, George P, Pooler P, Zaman A, Savani RC, Koval M (2001) Heterocellular gap junctional communication between alveolar epithelial cells. Am J Physiol Lung Cell Mol Physiol 280(6):L1085-L1093

27. Isakson BE, Evans WH, Boitano S (2001) Intercellular $\mathrm{Ca}^{2+}$ signaling in alveolar epithelial cells through gap junctions and by extracellular ATP. Am J Physiol Lung Cell Mol Physiol 280(2):L221-L228

28. De Vuyst E, Decrock E, De Bock M, Yamasaki H, Naus CC, Evans WH, Leybaert L (2007) Connexin hemichannels and gap junction channels are differentially influenced by lipopolysaccharide and basic fibroblast growth factor. Mol Biol Cell 18(1):34-46. doi:10.1091/mbc.E06-03-0182

29. Westphalen K, Gusarova GA, Islam MN, Subramanian M, Cohen TS, Prince AS, Bhattacharya J (2014) Sessile alveolar macrophages communicate with alveolar epithelium to modulate immunity. Nature 506(7489):503-506. doi:10.1038/ nature 12902

30. Parthasarathi K, Ichimura H, Monma E, Lindert J, Quadri S, Issekutz A, Bhattacharya J (2006) Connexin 43 mediates spread of $\mathrm{Ca}^{2+}$-dependent proinflammatory responses in lung capillaries. J Clin Invest 116(8):2193-2200. doi:10.1172/JCI26605

31. Sarieddine MZ, Scheckenbach KE, Foglia B, Maass K, Garcia I, Kwak BR, Chanson M (2009) Connexin43 modulates neutrophil recruitment to the lung. J Cell Mol Med 13(11-12):4560-4570. doi:10.1111/j.1582-4934.2008.00654.x

32. Chadjichristos CE, Scheckenbach KE, van Veen TA, Richani Sarieddine MZ, de Wit C, Yang Z, Roth I, Bacchetta M, Viswambharan H, Foglia B, Dudez T, van Kempen MJ, Coenjaerts FE, Miquerol L, Deutsch U, Jongsma HJ, Chanson M, Kwak BR (2010) Endothelial-specific deletion of connexin40 promotes atherosclerosis by increasing CD73-dependent leukocyte adhesion. Circulation 121(1):123-131. doi:10.1161/ CIRCULATIONAHA.109.867176

33. Lohman AW, Billaud M, Straub AC, Johnstone SR, Best AK, Lee M, Barr K, Penuela S, Laird DW, Isakson BE (2012) Expression of pannexin isoforms in the systemic murine arterial network. J Vasc Res 49(5):405-416. doi:10.1159/000338758

34. Pelegrin P, Surprenant A (2006) Pannexin-1 mediates large pore formation and interleukin-1beta release by the ATP-gated P2X7 receptor. EMBO J 25(21):5071-5082. doi:10.1038/sj.emboj. 7601378

35. Ruttenstock EM, Doni T, Dingemann J, Puri P (2012) Prenatal retinoic acid upregulates connexin $43(\mathrm{Cx} 43)$ gene expression in pulmonary hypoplasia in the nitrofen-induced congenital diaphragmatic hernia rat model. J Pediatr Surg 47(2):336-340. doi:10.1016/j.jpedsurg.2011.11.026

36. Reaume AG, de Sousa PA, Kulkarni S, Langille BL, Zhu D, Davies TC, Juneja SC, Kidder GM, Rossant J (1995) Cardiac malformation in neonatal mice lacking connexin43. Science 267(5205):1831-1834

37. Nagata K, Masumoto K, Esumi G, Teshiba R, Yoshizaki K, Fukumoto S, Nonaka K, Taguchi T (2009) Connexin43 plays an important role in lung development. J Pediatr Surg 44(12):2296-2301. doi:10.1016/j.jpedsurg.2009.07.070

38. Liao Y, Day KH, Damon DN, Duling BR (2001) Endothelial cell-specific knockout of connexin 43 causes hypotension and bradycardia in mice. Proc Natl Acad Sci USA 98(17):9989-9994. doi:10.1073/pnas.171305298

39. Simon AM, McWhorter AR (2002) Vascular abnormalities in mice lacking the endothelial gap junction proteins connexin37 and connexin40. Dev Biol 251(2):206-220

40. de Wit C, Roos F, Bolz SS, Kirchhoff S, Kruger O, Willecke K, Pohl U (2000) Impaired conduction of vasodilation along arterioles in connexin40-deficient mice. Circ Res 86(6):649-655 
41. Koval M, Billaud M, Straub AC, Johnstone SR, Zarbock A, Duling BR, Isakson BE (2011) Spontaneous lung dysfunction and fibrosis in mice lacking connexin 40 and endothelial cell connexin 43. Am J Pathol 178(6):2536-2546. doi:10.1016/j. ajpath.2011.02.045

42. Trovato-Salinaro A, Trovato-Salinaro E, Failla M, Mastruzzo C, Tomaselli V, Gili E, Crimi N, Condorelli DF, Vancheri C (2006) Altered intercellular communication in lung fibroblast cultures from patients with idiopathic pulmonary fibrosis. Respir Res 7:122. doi:10.1186/1465-9921-7-122

43. Vancheri C (2013) Common pathways in idiopathic pulmonary fibrosis and cancer. Eur Respir Rev 22(129):265-272. doi:10. 1183/09059180.00003613

44. Trosko JE, Ruch RJ (2002) Gap junctions as targets for cancer chemoprevention and chemotherapy. Curr Drug Targets 3(6):465-482

45. Yoon BI, Hirabayashi Y, Kawasaki Y, Tsuboi I, Ott T, Kodama Y, Kanno J, Kim DY, Willecke K, Inoue T (2004) Exacerbation of benzene pneumotoxicity in connexin 32 knockout mice: enhanced proliferation of CYP2E1-immunoreactive alveolar epithelial cells. Toxicology 195(1):19-29

46. King TJ, Lampe PD (2004) The gap junction protein connexin32 is a mouse lung tumor suppressor. Cancer Res 64(20):7191-7196. doi:10.1158/0008-5472.CAN-04-0624

47. King TJ, Gurley KE, Prunty J, Shin JL, Kemp CJ, Lampe PD (2005) Deficiency in the gap junction protein connexin32 alters p27Kip1 tumor suppression and MAPK activation in a tissuespecific manner. Oncogene 24(10):1718-1726. doi:10.1038/sj. onc. 1208355

48. Fukumasu H, Avanzo JL, Sanches DS, Mennecier G, Mori CM, Dagli ML (2013) Higher susceptibility of spontaneous and NNK-induced lung neoplasms in connexin 43 deficient CD1x AJ F1 mice: paradoxical expression of connexin 43 during lung carcinogenesis. Mol Carcinog 52(7):497-506. doi:10.1002/mc. 21884

49. de Oliveira KD, Tedardi MV, Cogliati B, Dagli ML (2013) Higher incidence of lung adenocarcinomas induced by DMBA in connexin 43 heterozygous knockout mice. Biomed Res Int 2013:618475. doi: $10.1155 / 2013 / 618475$

50. Avanzo JL, Mennecier G, Mesnil M, Hernandez-Blazquez FJ, Fukumasu H, da Silva TC, Rao KV, Dagli ML (2007) Deletion of a single allele of $\mathrm{Cx} 43$ is associated with a reduction in the gap junctional intercellular communication and increased cell proliferation of mouse lung pneumocytes type II. Cell Prolif 40(3):411-421. doi:10.1111/j.1365-2184.2007.00440.x

51. Ito A, Koma Y, Uchino K, Okada T, Ohbayashi C, Tsubota N, Okada M (2006) Increased expression of connexin 26 in the invasive component of lung squamous cell carcinoma: significant correlation with poor prognosis. Cancer Lett 234(2):239-248. doi:10.1016/j.canlet.2005.03.049

52. Cronier L, Crespin S, Strale PO, Defamie N, Mesnil M (2009) Gap junctions and cancer: new functions for an old story. Antioxid Redox Signal 11(2):323-338. doi:10.1089/ars.2008. 2153

53. Celetti SJ, Cowan KN, Penuela S, Shao Q, Churko J, Laird DW (2010) Implications of pannexin 1 and pannexin 3 for keratinocyte differentiation. J Cell Sci 123(Pt 8):1363-1372. doi: $10.1242 /$ jes. 056093

54. Vogt A, Hormuzdi SG, Monyer H (2005) Pannexin1 and Pannexin2 expression in the developing and mature rat brain. Brain Res Mol Brain Res 141(1):113-120. doi:10.1016/j.molbrainres. 2005.08.002

55. Swayne LA, Sorbara CD, Bennett SA (2010) Pannexin 2 is expressed by postnatal hippocampal neural progenitors and modulates neuronal commitment. J Biol Chem 285(32):24977-24986. doi:10.1074/jbc.M110.130054
56. Iwamoto T, Nakamura T, Doyle A, Ishikawa M, de Vega S, Fukumoto S, Yamada Y (2010) Pannexin 3 regulates intracellular ATP/cAMP levels and promotes chondrocyte differentiation. J Biol Chem 285(24):18948-18958. doi:10.1074/jbc.M110. 127027

57. Ishikawa M, Iwamoto T, Nakamura T, Doyle A, Fukumoto S, Yamada Y (2011) Pannexin 3 functions as an ER $\mathrm{Ca}(2+)$ channel, hemichannel, and gap junction to promote osteoblast differentiation. J Cell Biol 193(7):1257-1274. doi:10.1083/jcb. 201101050

58. Lai CP, Bechberger JF, Thompson RJ, MacVicar BA, Bruzzone R, Naus CC (2007) Tumor-suppressive effects of pannexin 1 in C6 glioma cells. Cancer Res 67(4):1545-1554. doi:10.1158/ 0008-5472.CAN-06-1396

59. Lai CP, Bechberger JF, Naus CC (2009) Pannexin2 as a novel growth regulator in C6 glioma cells. Oncogene 28(49):4402-4408. doi:10.1038/onc.2009.283

60. Cowan KN, Langlois S, Penuela S, Cowan BJ, Laird DW (2012) Pannexin1 and Pannexin3 exhibit distinct localization patterns in human skin appendages and are regulated during keratinocyte differentiation and carcinogenesis. Cell Commun Adhes 19(3-4):45-53. doi:10.3109/15419061.2012.712575

61. Penuela S, Gyenis L, Ablack A, Churko JM, Berger AC, Litchfield DW, Lewis JD, Laird DW (2012) Loss of pannexin 1 attenuates melanoma progression by reversion to a melanocytic phenotype. J Biol Chem 287(34):29184-29193. doi:10.1074/jbc. M112.377176

62. Penuela S, Kelly JJ, Churko JM, Barr KJ, Berger AC, Laird DW (2014) Panx1 regulates cellular properties of keratinocytes and dermal fibroblasts in skin development and wound healing. J Invest Dermatol 134(7):2026-2035. doi:10.1038/jid.2014.86

63. Knowles MR, Boucher RC (2002) Mucus clearance as a primary innate defense mechanism for mammalian airways. J Clin Invest 109(5):571-577. doi:10.1172/JCI15217

64. Fahy JV, Dickey BF (2010) Airway mucus function and dysfunction. N Engl J Med 363(23):2233-2247. doi:10.1056/ NEJMra0910061

65. Sanderson MJ, Chow I, Dirksen ER (1988) Intercellular communication between ciliated cells in culture. Am J Physiol 254(1 Pt 1):C63-C74

66. Boitano S, Dirksen ER, Sanderson MJ (1992) Intercellular propagation of calcium waves mediated by inositol trisphosphate. Science 258(5080):292-295

67. Davis CW, Lazarowski E (2008) Coupling of airway ciliary activity and mucin secretion to mechanical stresses by purinergic signaling. Respir Physiol Neurobiol 163(1-3):208-213. doi:10.1016/j.resp.2008.05.015

68. Homolya L, Steinberg TH, Boucher RC (2000) Cell to cell communication in response to mechanical stress via bilateral release of ATP and UTP in polarized epithelia. J Cell Biol 150(6): 1349-1360

69. Ohbuchi T, Takenaga F, Hohchi N, Wakasugi T, Ueta Y, Suzuki $\mathrm{H}$ (2014) Possible contribution of pannexin-1 to ATP release in human upper airway epithelia. Physiol Rep 2(2):e00227. doi:10. $1002 /$ phy 2.227

70. Seminario-Vidal L, Okada SF, Sesma JI, Kreda SM, van Heusden CA, Zhu Y, Jones LC, O'Neal WK, Penuela S, Laird DW, Boucher RC, Lazarowski ER (2011) Rho signaling regulates pannexin 1-mediated ATP release from airway epithelia. J Biol Chem 286(30):26277-26286. doi:10.1074/jbc.M111. 260562

71. Seminario-Vidal L, Kreda S, Jones L, O’Neal W, Trejo J, Boucher RC, Lazarowski ER (2009) Thrombin promotes release of ATP from lung epithelial cells through coordinated activation of rho- and $\mathrm{Ca}^{2+}$-dependent signaling pathways. J Biol Chem 284(31):20638-20648. doi:10.1074/jbc.M109.004762 
72. Richter K, Kiefer KP, Grzesik BA, Clauss WG, Fronius M (2014) Hydrostatic pressure activates ATP-sensitive $\mathrm{K}^{+}$channels in lung epithelium by ATP release through pannexin and connexin hemichannels. FASEB J 28(1):45-55. doi:10.1096/fj. 13-229252

73. Kreda SM, Seminario-Vidal L, van Heusden CA, O'Neal W, Jones L, Boucher RC, Lazarowski ER (2010) Receptor-promoted exocytosis of airway epithelial mucin granules containing a spectrum of adenine nucleotides. J Physiol 588(Pt 12):2255-2267. doi:10.1113/jphysiol.2009.186643

74. Randell SH, Boucher RC, University of North Carolina Virtual Lung G, (2006) Effective mucus clearance is essential for respiratory health. Am J Respir Cell Mol Biol 35(1):20-28. doi:10. 1165/rcmb.2006-0082SF

75. Wine JJ, Joo NS (2004) Submucosal glands and airway defense. Proc Am Thorac Soc 1(1):47-53. doi:10.1513/pats.2306015

76. Scheckenbach KE, Losa D, Dudez T, Bacchetta M, O'Grady S, Crespin S, Chanson M (2011) Prostaglandin E(2)regulation of cystic fibrosis transmembrane conductance regulator activity and airway surface liquid volume requires gap junctional communication. Am J Respir Cell Mol Biol 44(1):74-82. doi:10. 1165/rcmb.2009-03610C

77. Higgins G, Buchanan P, Perriere M, Al-Alawi M, Costello RW, Verriere V, McNally P, Harvey BJ, Urbach V (2014) Activation of P2RY11 and ATP release by lipoxin A4 restores the airway surface liquid layer and epithelial repair in cystic fibrosis. Am J Respir Cell Mol Biol 51(2):178-190. doi:10.1165/rcmb.20120424OC

78. Verriere V, Higgins G, Al-Alawi M, Costello RW, McNally P, Chiron R, Harvey BJ, Urbach V (2012) Lipoxin A4 stimulates calcium-activated chloride currents and increases airway surface liquid height in normal and cystic fibrosis airway epithelia. PLoS ONE 7(5):e37746. doi:10.1371/journal.pone.0037746

79. Al-Alawi M, Buchanan P, Verriere V, Higgins G, McCabe O, Costello RW, McNally P, Urbach V, Harvey BJ (2014) Physiological levels of lipoxin A4 inhibit ENaC and restore airway surface liquid height in cystic fibrosis bronchial epithelium. Physiol Rep. doi:10.14814/phy2.12093

80. Kovach MA, Standiford TJ (2011) Toll like receptors in diseases of the lung. Int Immunopharmacol 11(10):1399-1406. doi:10. 1016/j.intimp.2011.05.013

81. Barton GM, Kagan JC (2009) A cell biological view of toll-like receptor function: regulation through compartmentalization. Nat Rev Immunol 9(8):535-542. doi:10.1038/nri2587

82. Henson PM, Tuder RM (2008) Apoptosis in the lung: induction, clearance and detection. Am J Physiol Lung Cell Mol Physiol 294(4):L601-L611. doi:10.1152/ajplung.00320.2007

83. Hertz CJ, Wu Q, Porter EM, Zhang YJ, Weismuller KH, Godowski PJ, Ganz T, Randell SH, Modlin RL (2003) Activation of toll-like receptor 2 on human tracheobronchial epithelial cells induces the antimicrobial peptide human beta defensin-2. J Immunol 171(12):6820-6826

84. Yu FS, Cornicelli MD, Kovach MA, Newstead MW, Zeng X, Kumar A, Gao N, Yoon SG, Gallo RL, Standiford TJ (2010) Flagellin stimulates protective lung mucosal immunity: role of cathelicidin-related antimicrobial peptide. $\mathrm{J}$ Immunol 185(2):1142-1149. doi:10.4049/jimmunol.1000509

85. Ben Mohamed F, Garcia-Verdugo I, Medina M, Balloy V, Chignard M, Ramphal R, Touqui L (2012) A crucial role of Flagellin in the induction of airway mucus production by Pseudomonas aeruginosa. PLoS ONE 7(7):e39888. doi:10. 1371/journal.pone.0039888

86. Kunzelmann K, Scheidt K, Scharf B, Ousingsawat J, Schreiber R, Wainwright B, McMorran B (2006) Flagellin of Pseudomonas aeruginosa inhibits $\mathrm{Na}^{+}$transport in airway epithelia. FASEB J 20(3):545-546. doi:10.1096/fj.05-4454fje
87. Illek B, Fu Z, Schwarzer C, Banzon T, Jalickee S, Miller SS, Machen TE (2008) Flagellin-stimulated Cl- secretion and innate immune responses in airway epithelia: role for p38. Am J Physiol Lung Cell Mol Physiol 295(4):L531-L542. doi:10.1152/ ajplung.90292.2008

88. Buyck JM, Verriere V, Benmahdi R, Higgins G, Guery B, Matran R, Harvey BJ, Faure K, Urbach V (2013) P. aeruginosa LPS stimulates calcium signaling and chloride secretion via CFTR in human bronchial epithelial cells. J Cyst Fibros 12(1):60-67. doi:10.1016/j.jcf.2012.06.007

89. Martin FJ, Prince AS (2008) TLR2 regulates gap junction intercellular communication in airway cells. J Immunol 180(7):4986-4993

90. Chanson M, Berclaz PY, Scerri I, Dudez T, Wernke-Dollries K, Pizurki L, Pavirani A, Fiedler MA, Suter S (2001) Regulation of gap junctional communication by a pro-inflammatory cytokine in cystic fibrosis transmembrane conductance regulator-expressing but not cystic fibrosis airway cells. Am J Pathol 158(5):1775-1784. doi:10.1016/S0002-9440(10)64133-8

91. Huang S, Jornot L, Wiszniewski L, Rochat T, Suter S, Lacroix JS, Chanson M (2003) Src signaling links mediators of inflammation to $\mathrm{Cx} 43$ gap junction channels in primary and transformed CFTRexpressing airway cells. Cell Commun Adhes 10(4-6):279-285

92. Huang S, Dudez T, Scerri I, Thomas MA, Giepmans BN, Suter S, Chanson M (2003) Defective activation of c-Src in cystic fibrosis airway epithelial cells results in loss of tumor necrosis factor-alpha-induced gap junction regulation. J Biol Chem 278(10):8326-8332. doi:10.1074/jbc.M208264200

93. Rowe SM, Miller S, Sorscher EJ (2005) Cystic fibrosis. N Engl J Med 352(19):1992-2001. doi:10.1056/NEJMra043184

94. Losa D, Kohler T, Bellec J, Dudez T, Crespin S, Bacchetta M, Boulanger P, Hong SS, Morel S, Nguyen TH, van Delden C, Chanson M (2014) Pseudomonas aeruginosa-induced apoptosis in airway epithelial cells is mediated by gap junctional communication in a JNK-dependent manner. J Immunol 192(10):4804-4812. doi:10.4049/jimmunol.1301294

95. Grassme H, Kirschnek S, Riethmueller J, Riehle A, von Kurthy G, Lang F, Weller M, Gulbins E (2000) CD95/CD95 ligand interactions on epithelial cells in host defense to Pseudomonas aeruginosa. Science 290(5491):527-530

96. Cannon CL, Kowalski MP, Stopak KS, Pier GB (2003) Pseudomonas aeruginosa-induced apoptosis is defective in respiratory epithelial cells expressing mutant cystic fibrosis transmembrane conductance regulator. Am J Respir Cell Mol Biol 29(2):188-197. doi:10.1165/rcmb.4898

97. Grassme H, Becker KA, Zhang Y, Gulbins E (2010) CFTRdependent susceptibility of the cystic fibrosis-host to Pseudomonas aeruginosa. Int J Med Microbiol 300(8):578-583. doi:10.1016/j.ijmm.2010.08.011

98. Wansleeben C, Barkauskas CE, Rock JR, Hogan BL (2013) Stem cells of the adult lung: their development and role in homeostasis, regeneration, and disease. Wiley Interdiscip Rev Dev Biol 2(1):131-148. doi:10.1002/wdev.58

99. Buchanan PJ, McNally P, Harvey BJ, Urbach V (2013) Lipoxin A(4)-mediated KATP potassium channel activation results in cystic fibrosis airway epithelial repair. Am J Physiol Lung Cell Mol Physiol 305(2):L193-L201. doi:10.1152/ajplung.00058. 2013

100. Crespin S, Bacchetta M, Bou Saab J, Tantilipikorn P, Bellec J, Dudez T, Nguyen TH, Kwak BR, Lacroix JS, Huang S, Wiszniewski L, Chanson M (2014) Cx26 regulates proliferation of repairing basal airway epithelial cells. Int J Biochem Cell Biol 52:152-160. doi:10.1016/j.biocel.2014.02.010

101. Chandrasekhar A, Kalmykov EA, Polusani SR, Mathis SA, Zucker SN, Nicholson BJ (2013) Intercellular redistribution of cAMP underlies selective suppression of cancer cell growth by 
connexin26. PLoS ONE 8(12):e82335. doi:10.1371/journal. pone. 0082335

102. Shiner EK, Rumbaugh KP, Williams SC (2005) Inter-kingdom signaling: deciphering the language of acyl homoserine lactones. FEMS Microbiol Rev 29(5):935-947. doi:10.1016/j.femsre. 2005.03.001

103. Losa D, Kohler T, Bacchetta M, Bou Saab J, Frieden M, van Delden C, Chanson M (2015) Airway epithelial cell integrity protects from cytotoxicity of $P$. aeruginosa quorum-sensing signals. Am J Respir Cell Mol Biol. doi:10.1165/rcmb.201404050C

104. Ward JP, McMurtry IF (2009) Mechanisms of hypoxic pulmonary vasoconstriction and their roles in pulmonary hypertension: new findings for an old problem. Curr Opin Pharmacol 9(3):287-296. doi:10.1016/j.coph.2009.02.006

105. Wang L, Yin J, Nickles HT, Ranke H, Tabuchi A, Hoffmann J, Tabeling C, Barbosa-Sicard E, Chanson M, Kwak BR, Shin HS, Wu S, Isakson BE, Witzenrath M, de Wit C, Fleming I, Kuppe H, Kuebler WM (2012) Hypoxic pulmonary vasoconstriction requires connexin 40-mediated endothelial signal conduction. J Clin Invest 122(11):4218-4230. doi:10.1172/JCI59176

106. Yen CH, Leu S, Lin YC, Kao YH, Chang LT, Chua S, Fu M, Wu CJ, Sun CK, Yip HK (2010) Sildenafil limits monocrotalineinduced pulmonary hypertension in rats through suppression of pulmonary vascular remodeling. J Cardiovasc Pharmacol 55(6):574-584. doi:10.1097/FJC.0b013e3181d9f5f4

107. Billaud M, Dahan D, Marthan R, Savineau JP, Guibert C (2011) Role of the gap junctions in the contractile response to agonists in pulmonary artery from two rat models of pulmonary hypertension. Respir Res 12:30. doi:10.1186/1465-9921-12-30

108. Ichimura H, Parthasarathi K, Lindert J, Bhattacharya J (2006) Lung surfactant secretion by interalveolar $\mathrm{Ca}^{2+}$ signaling. Am J Physiol Lung Cell Mol Physiol 291(4):L596-L601. doi:10.1152/ ajplung.00036.2006

109. Patel AS, Reigada D, Mitchell CH, Bates SR, Margulies SS, Koval M (2005) Paracrine stimulation of surfactant secretion by extracellular ATP in response to mechanical deformation. Am J Physiol Lung Cell Mol Physiol 289(3):L489-L496. doi:10.1152/ ajplung.00074.2005

110. Ashino Y, Ying X, Dobbs LG, Bhattacharya J (2000) $\left[\mathrm{Ca}\left({ }^{2+}\right)\right](\mathrm{i})$ oscillations regulate type II cell exocytosis in the pulmonary alveolus. Am J Physiol Lung Cell Mol Physiol 279(1):L5-L13

111. Wang PM, Fujita E, Bhattacharya J (2002) Vascular regulation of type II cell exocytosis. Am J Physiol Lung Cell Mol Physiol 282(5):L912-L916. doi:10.1152/ajplung.00303.2001

112. Schroder K, Tschopp J (2010) The inflammasomes. Cell 140(6):821-832. doi:10.1016/j.cell.2010.01.040

113. Qu Y, Misaghi S, Newton K, Gilmour LL, Louie S, Cupp JE, Dubyak GR, Hackos D, Dixit VM (2011) Pannexin-1 is required for ATP release during apoptosis but not for inflammasome activation. J Immunol 186(11):6553-6561. doi:10.4049/ jimmunol.1100478

114. Cohen TS, Prince AS (2013) Activation of inflammasome signaling mediates pathology of acute $P$. aeruginosa pneumonia. J Clin Invest 123(4):1630-1637. doi:10.1172/JCI66142

115. Wonnenberg B, Tschernig T, Voss M, Bischoff M, Meier C, Schirmer SH, Langer F, Bals R, Beisswenger C (2014) Probenecid reduces infection and inflammation in acute Pseudomonas aeruginosa pneumonia. Int J Med Microbiol 304(5-6):725-729. doi:10.1016/j.ijmm.2014.05.002

116. Kafka D, Ling E, Feldman G, Benharroch D, Voronov E, GivonLavi N, Iwakura Y, Dagan R, Apte RN, Mizrachi-Nebenzahl Y (2008) Contribution of IL-1 to resistance to Streptococcus pneumoniae infection. Int Immunol 20(9):1139-1146. doi:10. 1093/intimm/dxn071
117. McNeela EA, Burke A, Neill DR, Baxter C, Fernandes VE, Ferreira D, Smeaton S, El-Rachkidy R, McLoughlin RM, Mori A, Moran B, Fitzgerald KA, Tschopp J, Petrilli V, Andrew PW, Kadioglu A, Lavelle EC (2010) Pneumolysin activates the NLRP3 inflammasome and promotes proinflammatory cytokines independently of TLR4. PLoS Pathog 6(11):e1001191. doi:10. 1371/journal.ppat.1001191

118. Junger WG (2011) Immune cell regulation by autocrine purinergic signalling. Nat Rev Immunol 11(3):201-212. doi:10. 1038/nri2938

119. Chen Y, Yao Y, Sumi Y, Li A, To UK, Elkhal A, Inoue Y, Woehrle T, Zhang Q, Hauser C, Junger WG (2010) Purinergic signaling: a fundamental mechanism in neutrophil activation. Sci Signal 3(125):ra45. doi:10.1126/scisignal.2000549

120. Bao Y, Chen Y, Ledderose C, Li L, Junger WG (2013) Pannexin 1 channels link chemoattractant receptor signaling to local excitation and global inhibition responses at the front and back of polarized neutrophils. J Biol Chem 288(31):22650-22657. doi:10.1074/jbc.M113.476283

121. Burnstock G, Brouns I, Adriaensen D, Timmermans JP (2012) Purinergic signaling in the airways. Pharmacol Rev 64(4):834-868. doi:10.1124/pr.111.005389

122. Riteau N, Gasse P, Fauconnier L, Gombault A, Couegnat M, Fick L, Kanellopoulos J, Quesniaux VF, Marchand-Adam S, Crestani B, Ryffel B, Couillin I (2010) Extracellular ATP is a danger signal activating $\mathrm{P} 2 \mathrm{X} 7$ receptor in lung inflammation and fibrosis. Am J Respir Crit Care Med 182(6):774-783. doi:10. 1164/rccm.201003-0359OC

123. Wong CW, Christen T, Roth I, Chadjichristos CE, Derouette JP, Foglia BF, Chanson M, Goodenough DA, Kwak BR (2006) Connexin 37 protects against atherosclerosis by regulating monocyte adhesion. Nat Med 12(8):950-954. doi:10.1038/ nm1441

124. Eltzschig HK, Eckle T, Mager A, Kuper N, Karcher C, Weissmuller T, Boengler K, Schulz R, Robson SC, Colgan SP (2006) ATP release from activated neutrophils occurs via connexin 43 and modulates adenosine-dependent endothelial cell function. Circ Res 99(10):1100-1108. doi:10.1161/01.RES.0000250174. 31269.70

125. Zhang J, Wang W, Sun J, Li Q, Liu J, Zhu H, Chen T, Wang H, Yu S, Sun G, Chen W, Yi D (2010) Gap junction channel modulates pulmonary vascular permeability through calcium in acute lung injury: an experimental study. Respiration 80(3):236-245. doi:10.1159/000274384

126. Li Q, Zhang J, Wang W, Liu J, Zhu H, Chen W, Chen T, Yu S, Wang H, Sun G, Yi D (2010) Connexin40 modulates pulmonary permeability through gap junction channel in acute lung injury after thoracic gunshot wounds. J Trauma 68(4):802-809. doi:10. 1097/TA.0b013e3181bb80ea

127. Rignault S, Haefliger JA, Waeber B, Liaudet L, Feihl F (2007) Acute inflammation decreases the expression of connexin 40 in mouse lung. Shock 28(1):78-85. doi:10.1097/shk.0b013e3180310bd1

128. Eckle T, Koeppen M, Eltzschig HK (2009) Role of extracellular adenosine in acute lung injury. Physiology (Bethesda) 24:298-306. doi:10.1152/physiol.00022.2009

129. Lennon PF, Taylor CT, Stahl GL, Colgan SP (1998) Neutrophilderived $5^{\prime}$-adenosine monophosphate promotes endothelial barrier function via CD73-mediated conversion to adenosine and endothelial A2B receptor activation. J Exp Med 188(8):1433-1443

130. Kasper M, Traub O, Reimann T, Bjermer L, Grossmann H, Muller M, Wenzel KW (1996) Upregulation of gap junction protein connexin43 in alveolar epithelial cells of rats with radiation-induced pulmonary fibrosis. Histochem Cell Biol 106(4):419-424

131. Parthasarathi K (2012) Endothelial connexin 43 mediates acidinduced increases in pulmonary microvascular permeability. Am 
J Physiol Lung Cell Mol Physiol 303(1):L33-L42. doi:10.1152/ ajplung.00219.2011

132. Moreno AP, Chanson M, Elenes S, Anumonwo J, Scerri I, Gu H, Taffet SM, Delmar M (2002) Role of the carboxyl terminal of connexin43 in transjunctional fast voltage gating. Circ Res 90(4):450-457

133. Bhattacharya J, Matthay MA (2013) Regulation and repair of the alveolar-capillary barrier in acute lung injury. Annu Rev Physiol 75:593-615. doi:10.1146/annurev-physiol-030212-183756

134. Parekkadan B, Milwid JM (2010) Mesenchymal stem cells as therapeutics. Annu Rev Biomed Eng 12:87-117. doi:10.1146/ annurev-bioeng-070909-105309

135. Lama VN, Smith L, Badri L, Flint A, Andrei AC, Murray S, Wang Z, Liao H, Toews GB, Krebsbach PH, Peters-Golden M, Pinsky DJ, Martinez FJ, Thannickal VJ (2007) Evidence for tissue-resident mesenchymal stem cells in human adult lung from studies of transplanted allografts. J Clin Invest 117(4):989-996. doi:10.1172/JCI29713
136. Badri L, Walker NM, Ohtsuka T, Wang Z, Delmar M, Flint A, Peters-Golden M, Toews GB, Pinsky DJ, Krebsbach PH, Lama VN (2011) Epithelial interactions and local engraftment of lungresident mesenchymal stem cells. Am J Respir Cell Mol Biol 45(4):809-816. doi:10.1165/rcmb.2010-0446OC

137. Islam MN, Das SR, Emin MT, Wei M, Sun L, Westphalen K, Rowlands DJ, Quadri SK, Bhattacharya S, Bhattacharya J (2012) Mitochondrial transfer from bone-marrow-derived stromal cells to pulmonary alveoli protects against acute lung injury. Nat Med 18(5):759-765. doi:10.1038/nm.2736

138. Beahm DL, Oshima A, Gaietta GM, Hand GM, Smock AE, Zucker SN, Toloue MM, Chandrasekhar A, Nicholson BJ, Sosinsky GE (2006) Mutation of a conserved threonine in the third transmembrane helix of alpha- and beta-connexins creates a dominant-negative closed gap junction channel. J Biol Chem 281(12):7994-8009. doi:10.1074/jbc.M506533200 